\section{Grei innføring i medisinsk entomologi}

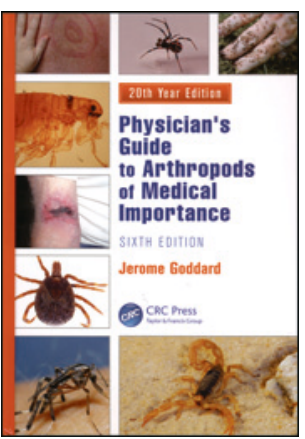

Jerome Goddard

Physician's guide to arthropods of medical importance

6. utg. 515 s, tab, ill. Boca Raton,

FL: CRC Press, 2013. Pris GBP 95

ISBN 978-1-4398-5085-5

Målgruppen er leger som ikke har noen kunnskaper i entomologi fra før, men som vil skaffe seg basiskunnskaper i dette faget. Det er en lærebok som egner seg godt til å lese fra perm til perm. Den egner seg også som oppslagsbok. Teksten er krydret med bokser med kasusbeskrivelser og ofte stilte spørsmål.

Boken er skrevet på lett forståelig engelsk, er solid innbundet og med god papirkvalitet. Det følger med en CD-ROM hvor det mest nyttige er en stor samling linker. Illustrasjonene er mange, både i form av fotografier, livssyklusdiagrammer og utbredelseskart. Som i andre gode entomologiske lærebøker baserer man seg hovedsakelig på tegninger av dyrene, men dessverre har utgiverne brukt lavoppløselige filer ved gjengivelse av tegningene. Det er synd, for i tillegg til at tegninger er til vesentlig hjelp i identifisering, består mye av gleden ved å lese entomologi nettopp i å se detaljerte tegninger. Her føles det som om øyet må slite for å finne fokus. For eksempel er det tatt med tegninger av 20 forskjellige myggarter og 26 flåttarter, men med så lite detaljer at tegningene ikke tjener til noe som helst. Det må imidlertid understrekes at dette ikke er en bok for artsidentifisering. Illustrasjonene tjener som eksempler på hva som finnes. En komplett artsidentifisering av alle leddyr med medisinsk betydning ville fylt hyllemetere. Det er rikelig med referanser for videre lesning.

Første del handler om sykdommer og plager forårsaket av leddyrene i seg selv: allergi, lokalreaksjoner, stikk, bitt og invasjon av menneskelig vev. Når noen kommer med utslett som de mener skyldes insektstikk, har de sjelden med seg dyret som har stukket dem. Her presenteres i tabellform en rekke holdepunkter for å sirkle inn hva som kan være årsaken. Jeg savner flere og bedre illustrasjoner av hvordan forskjellige stikk kan se ut.

I den andre delen tar forfatterne for seg systematikk og identifikasjon av leddyr på basalnivå. I tillegg er det en oversikt over hvilke symptomer og tegn som leddyrbårne sykdommer kan gi.

Tredje del er hoveddelen, hvor forfatteren går igjennom hver gruppe av leddyr som har medisinsk betydning. Her omtales utbredelse, utseende, biologi, hvilke plager leddyrene forårsaker, eventuelle sykdommer de kan overføre, og hvordan de kan bekjempes. Prioriteringene bærer noe preg av at boken er amerikansk.

Avslutningsvis er det en liten, men nyttig del om personlig beskyttelse.

Entomologi fortoner seg for mange som et uoverkommelig felt å gi seg i kast med, men denne boken kan være en god hjelp for infeksjons- og reisemedisinere til å komme i gang med dette fascinerende fagfeltet.

\section{Gunnar Hasle}

Reiseklinikken, Oslo

\section{Fødeepidural på amerikansk}

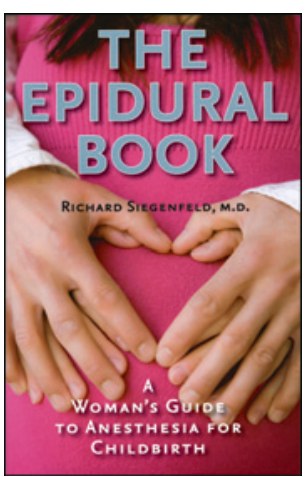

Richard Siegenfeld The epidural book

A woman's guide to anesthesia for childbirth 133 s, ill. Baltimore, MD: The John Hopkins University Press, 2012. Pris USD 16 ISBN 978-1-4214-0734-0

Boken er ment som informasjon om epiduralbedøvelse for gravide. Den har også noe informasjon om andre former for smertelindring under fødsel og ved keisersnitt. De 16 korte kapitlene har mange illustrasjoner. Både språk og illustrasjoner er enkle og har en humoristisk tone. Forfatteren gir grundig informasjon om når epiduralbedøvelse kan gis, hvordan det gjøres, hvordan den virker og om eventuelle bivirkninger.

Forfatteren er anestesilege fra USA, og han beskriver forholdene på nordamerikanske sykehus. Han er udelt positiv til epiduralbedøvelse, og det skinner tydelig gjennom at han synes det er unødvendig at kvinner skal oppleve fødselssmerter. Fødselssmertene blir beskrevet som negative, til og med som onde («evil»), og sammenliknet med smerter i forbindelse med kirurgiske inngrep eller tanntrekking. I illustrasjonene blir det å ha en god fødeepidural fremstilt som å ligge i en hengekøye under en kokospalme og kose seg. Riesmerter blir fremstilt som å ligge i den samme hengekøyen mens kokosnøttene faller ned i hodet på deg. Anestesilegen blir både i tekst og illustrasjoner beskrevet som en skytsengel.

Selv om bivirkningene blir gjennomgått, blir noen av dem tatt lett på. Spinalhodepine blir fremstilt som beklagelig, men det ordner seg etter et par dager med koffeinholdig drikke, smertestillende tabletter og ev-entuelt epidural blodlapp (blood patch). At dette også kan føre til problemer med tilknytningen til barnet, ammestart og barnestell nevnes ikke.

Forfatteren refererer flere ganger til den siste Cochrane-oversikten om fødeepidural (1) og viser til at det ikke er forskjeller i andel keisersnitt, ryggsmerter eller andre utfall hos kvinner som fikk epiduralbedøvelse sammenliknet med de som ikke fikk. Han nevner ikke at den samme oversikten heller ikke fant forskjeller i tilfredshet hos mødrene - de som ikke fikk epiduralbedøvelse, var akkurat like fornøyd med smertelindringen som de som fikk bedøvelsen.

Boken er kanskje både nyttig og informativ i USA. Forholdene ved norske fødeinstitusjoner er helt forskjellige fra dem som beskrives her. De fleste norske gravide er i utgangspunktet innstilt på å klare seg uten epiduralbedøvelse og heller ta stilling til smertelindring underveis i forløpet. Jordmødre og fødselsleger støtter og oppmuntrer vanligvis til dette.

Epiduralbedøvelse er et fantastisk hjelpemiddel for kvinner med langvarige og smertefulle fødsler, og det vil være nyttig med god og objektiv skriftlig informasjon om emnet. Jeg anbefaler imidlertid ikke denne boken til norske lesere.

\section{Ellen Blix}

Klinisk forskningsavdeling

Universitetssykehuset Nord-Norge

Tromsø

\section{Litteratur}

1. Anim-Somuah M, Smyth RMD, Jones L. Epidural versus non-epidural or no analgesia in labour. Cochrane Database Syst Rev 2011; nr. 12: CD000331. 